Journal of Social Sciences 6 (3): 424-428, 2010

ISSN 1549-3652

(C) 2010 Science Publications

\title{
Changing Public Policy Due to Saudi City of Jeddah Flood Disaster
}

\author{
Naill M. Momani and Ayman S. Fadil \\ Faculty of Economics and Administration, King Abdu Aziz University, \\ P.O. Box 80201, Jeddah 21589, Kingdom of Saudi Arabia
}

\begin{abstract}
Problem statement: This study discussed the last flood disaster which occurred in Jeddah City-Kingdom of Saudi Arabia in 25th of November 2009 which caused more than 121 fatalities and billions of dollars in losses in addition to around 20,000 sheltered families which cause a shift in public policy to deal with natural disasters in Saudi Arabia. Approach: We followed the flood disaster events starting from rain fall to the recovery stage. Then, timeline for the event is constructed with the intention to document and draw lessons for quick response in future disasters. Results: Natural causes and human errors and lack of clear public policy to deal with natural disasters were the most contributors to human and monetary losses due to the flood disaster in Jeddah City. Conclusion/Recommendations: It is necessary to have declared public policy for accountability which enable decision makers develop and implement policies and procedures, as well as plans to deal with natural and man-made disasters.
\end{abstract}

Key words: Flood disaster, disaster timeline, Jeddah flood disaster, disasters public policy

\section{INTRODUCTION}

The city of Jeddah on the west coast of the Kingdom of Saudi Arabia in the middle of the Red Sea, a total area of $748 \mathrm{~km}^{2}$ one of the most important cities in Saudi Arabia and the gateway to trade, which has gained great importance the movement of international trade with foreign markets. Jeddah is characterized as a main gate of the Two Holy Mosques and the first stop for the pilgrims and pilgrims coming to the leading of the Holy Land (Mecca and Medina) enters through the year to Jeddah's King Abdul Aziz International large numbers, up to 5 million people annually with the purpose of Hajj or Umrah or study or tourism and entertainment.

Jeddah is directly affected by the climate of their geographical location, with high temperature and humidity during the summer and temperatures of up to early forties centegrades, where the percentage under the influence of seasonal low over a warm air mass, solid and up to the higher humidity in the summer due to rising sea temperatures and lower in winter.

Jeddah is bounded to the south of the mountains from the east and the Red Sea to the west as shown in Fig. 1, we see that most of the development zones are located within the Tihama plain stretches in the area between the Red Sea coast in the east and mountains and mountains of the Hijaz Sarawat along the length of

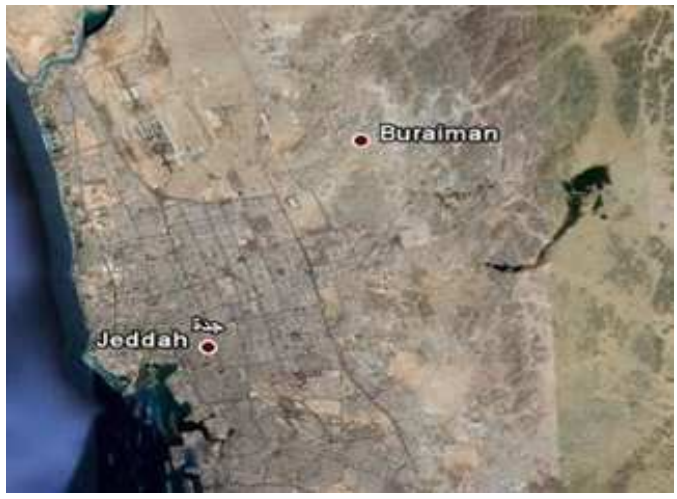

Fig. 1: Flood plain area for Jeddah city

the western province and most of these areas is land and plains by a slight decline from east to west vary from zero to $12.5 \mathrm{~m}$, on the other hand, the rainfall in the province of Jeddah, a rare and highly variable rates between the spray and light flash floods and help the nature of the ground exacerbate the problem due to limited land surface to absorb this water.

\section{MATERIALS AND METHODS}

We shed light on the chronology of events for the flood disaster with the intention to draw lessons from the decision making process that will facilitate

Corresponding Author: Naill M. Momani, Faculty of Economics and Administration, King Abdu Aziz University, P.O. Box 80201, Jeddah 21589, Kingdom of Saudi Arabia 
proposing and implementing future mitigation and preparedness measures to deal with such future events:

- Wednesday 25/11/2009, at 8 am: Rain lashing the coastal city of Jeddah and lasted for several hours without interruption and the outcome of initial reports the death of 10 citizens and save more than 100 people

- Thursday 26/11/2009: Saudi civil defense announces high death toll in the heavy rains and floods to 48 people and save 900 others trapped in rain and declares its use of rubber boats in the rescue operations

- Friday 27/11/2009: Director of Health Affairs in Jeddah invite parents to stay away from gatherings of water and torrential rains for fear of diseases that may cause and the announcement of the high death toll to 83 people, civil defense aircraft continues in its attempts to rescue caught up in the water

- Saturday 28/11/2009: Declaration of the high death toll to 106, the Saudi lawyer Waleed Abu Al Khair says he will sue Jeddah Municipality, stressing that the families of victims of the floods to support these endeavors and that he intended to condemn the failure of the sewerage system in the city

- Sunday 29/11/2009: Rescue attempts continued in the stricken city and media attention is unprecedented floods and the legacy of large numbers of victims and a book critical of Saudi Jeddah municipality, negligence and lack of appreciation of things well

- Monday 30/11/2009: Jeddah disaster cast a shadow on the travel of the traveling and the return of pilgrims to their countries because of delays in flights due to a breakdown in the building automation system inquiries, thus forcing the officials to end the proceedings traveler manually, while continuing the search for the missing

- Monday 30/11/2009: King Abdullah bin Abdul Aziz to form a commission to investigate the disaster, Jeddah and give the power to call any of the official inquiry, headed by the Prince Khalid bin Faisal, governor of Mecca and instructs the competent authorities for the payment of compensation of one million riyals for each victim's family and provide assistance and shelter all those affected by the floods

- Tuesday 1/12/2009: Start a commission of inquiry of its study and a tribute to wide attention the king and decided to form the Committee and provide emergency assistance for families of the victims, while authorities continue their efforts and the implementation of the precautionary plans are broad indicators of the stability of the Lake "musk". Which could cause a cascade threat to the city of Jeddah if flooded by rain

- Thursday 3/12/2009: the search for the missing continues and the announcement of the names of 108 dead by the floods and civil defense established attribution to the emergency center to monitor developments in flood and trapping Lake musk

- Saturday 5/12/2009: Committee formed by the king to investigate the disaster Jeddah hold its first meeting under the chairmanship of Prince Khalid Al Faisal, according to the outcome of the meeting it was decided to form several sub-committees have been entrusted with the tasks initially, at the top limit the damage and begin to arrange payment of subsidy governmental organizations for the families of the victims of $\$$ million riyals for each prisoner is dead

- Sunday 6/12/2009: Saudi Shura Council reaffirms its support for the study of the Commission of Inquiry in the catastrophe of Jeddah and pays tribute to the issuance of a royal order in this regard and suggests that he will study on his part up the impacts of catastrophic floods across Jeddah as guaranteed by the rules and powers of a regulatory source said the floods destroy the nanodevices and lost experience and research of 30 years at King Abdul-Aziz University

- Monday 7/12/2009: Seek citizens and residents involvement to provide information according to the investigation and begin to call people from inside and outside the secretariat of the Jeddah and prevention of vacation and traveling outside the Kingdom for engineers and experts to help in investigation

- Wednesday 9/12/2009: Media spokesman for the secretariat of the Jeddah talks to Ahmed al-Ghamdi Elaf "We are accused of ... and the investigation will not stop at al-Faqih". (al-Faqih is mayor of Jeddah City)

- Thursday 10/12/2009: Death toll rises to 116 dead and diminishing the chances of finding survivors.

- Saturday 12/12/2009: Civil Defense declared finding 5 victims from the same family in raising the death toll to 120 dead and reduced the number of missing to 32

- Thursday 17/12/2009: dwindling chances of finding survivors after the disaster and the death toll to 121 and the Investigation Commission continue its study without notice to the investigation 
- $\quad$ Sunday 20-12 2009: The number of deaths is 122 deaths and the number of missing dropped to 39 missing and the number who have been accommodated in the apartments amounted to 7167 the number of Saudi families 26131 persons, of whom 664 young bachelor, while the number of households that 221 families were sheltering 784 individuals

- Monday 21/12/2009: Death toll rises to 122, according to the statement of defense and civilian volunteer efforts accounted scene in Jeddah.

- Tuesday 22-12 2009: Citizens in a speech calling for people to "bring the perpetrators" in the "Jeddah disaster"

- Wednesday 23/12/2009: Hanager falling on electric wires due to rainfall and civil defense without cranes, rain Tuesday cut the current in Yanbu City, Jeddah citizens fears from flood return, $90 \%$ the proportion of students are absent and the cancellation of the afternoon shift

- Friday 25/12/2009: Unveiling the civil national defense will be within a week the announcement of results of the examination of DNA that was collected from about 30 families to identify some 25 unidentified bodies.

- The Custodian of the Two Holy Mosques King Abdullah bin Abdulaziz stressed the importance of identifying responsible for "Jeddah disaster" and hold accountable and said "will not compromise with any remiss in this respect"

- Monday 28/12/2009: A number of the Shura Council members said that the stop of 32 officials of Jeddah on Tuesday on the back of flood disaster strongly devoted to directives of the Custodian of the Two Holy Mosques King Abdullah bin Abdul Aziz to fight corruption and to prosecute any official careless in the performance of its mission. (Sharif, 2009)

- Wednesday 30/12/2009: Committee on "Truth" custody of the 25 employees of "Jeddah Municipality"

- Friday 20/02/2010: Investigation with contractors who did not support disaster relief efforts in Jeddah. The Ministry of Transport investigate the failures and shortcomings that have emerged from some contactors during the flood disaster which limit the ministry capabilities in implementing the provisions in the disaster management plan for Jeddah area to address potential risks in the future, such as floods, landslides and earthquakes

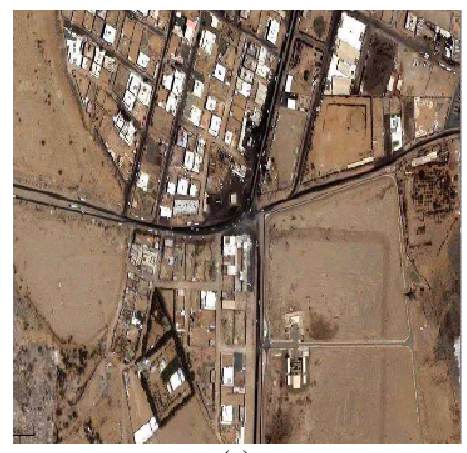

(a)

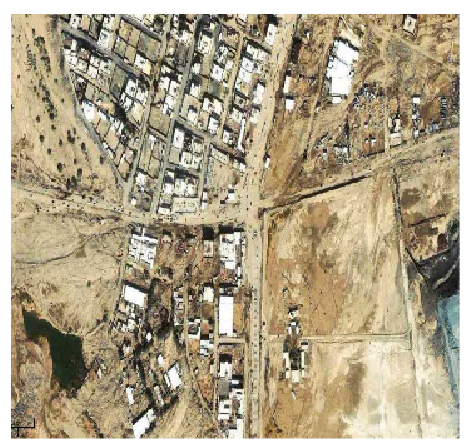

(b)

Fig. 2: The effects of the flood impacts of Jeddah City. (A): Before; (B): After

Disaster consequences: The city of Jeddah, commercial gate to the Kingdom of Saudi Arabia, including an estimated population of $14 \%$ of the population of Saudi Arabia, seen in 25/11/2009 what is known as a disaster of Black Wednesday, where a heavy rain for a period of 6 continuous hours lead to the deaths of more than 121 people with monetary losses in the rise. Figure 2 shows the flood effects for some areas within the city of Jeddah.

For the monetary losses amounted to about $\$ 3$ billion riyals, long installations and government facilities and compensation for those affected is estimated at 5.1 billion riyals. As for the number of deaths it has reached 121 and other sources, 122 cases with number of missing of 30 people. The number of sheltered was includes 26,711 people in furnished apartments and also pay subsistence for the families of 7821 people. An estimated of 11849 damaged properties and 10913 damaged cars. Commercial traffic was paralyzed and sales fell to about $60 \%$ in some shops and the fear of the spread of epidemics and diseases (dengue fever). What is more, it led to the destruction of farms along the road in length of about $100 \mathrm{~km}$. Some buildings get cracks such as residential buildings, shops, which led to the collapse of some 


\section{J. Social Sci., 6 (3): 424-428, 2010}

houses. In addition, some main and branch roads had washed away a number of cars and high water levels in residential neighborhoods. Floods also led to the displacement of hundreds of families during the crisis and the evacuation of homes in the affected districts and neighborhoods close to them during the crisis and then to avoid the rain later. As for the side effects of the disaster mental disorders have emerged, especially among children who lived through the suffering and frequent theft because thieves are waiting for what will be drawn by them as floods increased theft of equipment and cars and many more.

\section{RESULTS}

The city is located on the coast surrounded by sea and from the east and the plains of the Tihama are low to the Hijaz highlands to the west of the Red Sea, it is imperative that the city extends north and south at the expense of the sea due to a rapid increase of population density. This cause two problems:

- Reclamation areas from sea, which formed twothirds of the current city

- There is no solid infrastructure to contain the growth of population

Most of the rainfall that falls in Jeddah is accompanied by thunderstorms, the rains usually during the winter, as well as in the spring and autumn, as a result of the passage of depressions air from west to east and concur with Sudan over low heat on the region and the world dealing with this kind of devastating rain which is usually accompanied with sever and devastating winds.

Since the Tihama mountains surrounded by sea from the east and the west it is natural to move torrents from the east to the west and create these torrents a number of valleys, estuaries end to the Red Sea. Moreover, rising groundwater due to leakage of sewage and storm-water irrigation and rising sea level due to global climate change (Habib, 2009) and the rapid onset of the rain were the main reasons for the flood (Sahli, 2009).

\section{DISCUSSION}

There was a lack of disaster warning devices and systems both fixed and mobile ones in Jeddah which delay informing stakeholders and the population of heavy rainfall by the meteorological services which could use the Saudi Telecom to deliver messages to mobile customers of the population, as well as to inform the Saudi state television.
The search for missing bodies in Jeddah City took longer than expected since the Civil Defense did not use modern technologies to detect the missing bodies which delay the declaration of recovery stage in addition to the lack of cranes and some important necessities in such crises. This shortcoming could be due to lack of emergency management body to take over the task of knowing the needs of the city of Jeddah to deal with future disasters.

Consulting engineer Nizar Abdullah said that the real reason behind the Jeddah disaster was failure to maintain the floodplain and drainage channels which are established to protect the city of Jeddah. He said:

"In addition, there is another reason was the echo of water flowing from the valley in an easterly direction and turned to the south-east and its convergence with water from other valley which composed momentum high water, which led to the transformation towards the neighborhoods". Moreover, he added that "Echo is due to the closure of areas along the northern drainage channel yet fully allow the establishment of a residential district primarily to direct flood water to the channel established for the North to protect dangers of flooding for the city of Jeddah"

The flood disaster proved that failure to take precautions and preparation for natural disasters is a big mistake, especially if it came from government agencies that bear the responsibility to address all risks, including that resulting from natural disasters since they bear the responsibility for implementing and organizing rescue operations, evacuation and providing assistance in the event of any disaster and they should be able to take actions and policies that limit or reduce the risk of natural and man-made disasters. That is why the government agencies should identify ways to address these risks and develop programs ready for rescue if the event takes place. In the case of Jeddah Disaster, the growing governmental bureaucracy slowdown propose solutions despite prior knowledge of the dangers of floods that overwhelmed the city of Jeddah.

The recent event of Jeddah made an urgent need to develop mechanisms for reporting of natural hazards (and others) and take appropriate decisions to prevent, taking action and appropriate precautions to deal with before disaster strikes. With so many accusations of corruption after the floods Jeddah, there is a need to establish effective mechanisms to fight corruption and to address the abuse of power which many people blamed for the disabled storm water drainage projects and sewage since there was construction on land which 
is known for officials to be in the valleys or seas buried planned and sold to the people. Moreover, there was only $8 \%$ of the city covered with sewer system according to the Saudi Consulting Engineer Zaki Mohamed Farsi.

Lack of police and civil defense during the event of a disaster, where it encountered the disaster pilgrimage season increased the human and monetary losses. In this season, the Kingdom mobilize its security in the service of pilgrims and uniqueness of this season there are many threats that were causing concern to the State, including the war on Houthis (Yemen borders) and the threats of Iran and the swine flu and therefore has been to consolidate positions in Mecca and reduce the number of elements the security in Jeddah, which led to delays in rescue operations.

\section{CONCLUSION}

For the first time in Saudi Arabia a declaration by the roller to combat negligence behavior to deal with natural disasters among officials and decision makers. This change in public policy will enhance preparedness and response abilities to deal with natural and manmade disasters. Jeddah flood disasters proved that it is important to establish early warning system which must be linked with related departments such as traffic department and the Civil Defense and the National Guard and the Jeddah Municipality and the Department of Meteorology, government and private hospitals. Such system if implemented could warn affected communities and institutions of impending disasters. Large losses were due to corruption, therefore, there is a need to establish effective mechanisms to fight corruption and to address the abuse of power which many people blamed for the disabled storm water drainage and sewage projects as long as emphasizing on the relevant authorities to implement the ordinance that prevents the property and construction in valleys. In addition we recommend the following:

- Activating the role of maintenance of equipment and streams of rainfall in the rainy seasons and the use of meteorological and environmental protection in periods of rainfall in the province of Jeddah
- The Association of Meteorology and Environmental Protection must pursue a new approach in the process of notification and warning of rain and floods, so that affected communities could be warned before a disaster strike

- Preparation of hydrological studies to address the tendencies surface when creating new roads and maintenance of the old ones

- Develop awareness programs for preventing the dangers of rain and floods and activating the role of the community

- Review all regulations and plans related to the natural and man-made disasters management in the Kingdom

- Review and study all of the issued regulations related to urban planning, particularly with regard to identifying the urban boundaries of each city to identify shortcomings both in the regulations or the application

- Establishment of a national anti-corruption institutions which does not interfere with government ministries and non-governmental organizations in its study where it will completely independent financially and administratively to monitor projects and the budget of these institutions and government ministries

\section{REFERENCES}

Habib, S., 2009. Our cities between weather fluctuation and rainfall drainage. Al-Madina.com. http://www.al-madina.com/node/202155

Sahli, M., 2009. We informed the authorities one month ahead. OKAZ. http://www.okaz.com.sa/new/Issues/20091208/Con 20091208319314.htm

Sharif, S., 2009. Al Madina newspaper. AlMadina.com. http://al-madina.com/node/210185 